\title{
Bianca-Florentina Cheregi*
}

\section{Nation Branding in Romania After 1989: A Cultural Semiotic Perspective}

\begin{abstract}
This paper discusses four nation branding post-communist campaigns initiated by the Romanian Government, from a cultural semiotic perspective, as developed by the Tartu-Moscow-Semiotic School. In so doing, it focuses on analyzing advertising and national identity discourses inside the semiospheres. Moreover, the paper investigates how elements of neoliberal ideology are addressed in the governmental campaigns, considering the "marketization of public discourse" (Fairclough, 1993). Nation branding in post-communist Romania is a distinctive phenomena, compared to other countries, especially from Western Europe. In transition countries, nation branding is often mentioned because of the constant need to reconfigure national identity by dissociating from the communist past (Kaneva, 2012). In Romania, nation branding is also a public issue discussed in the media, connected to the ways in which the international press portrays the country or to the migrants' actions. In this context, Romania's nation brand represents a cultural space and the campaigns mobilize cultural symbols as systems of signs necessary for the existence and functioning of advertising discourses.

Using a semiotic analysis linked to the field of cultural semiotics (Lotman, 2005/1984), this article analyzes four nation branding campaigns initiated by the Romanian Government (Romania Simply Surprising - 2004, Romania Land of Choice - 2009, Explore the Carpathian Garden - 2010, and Discover the Place Where You Feel Reborn - 2014), considering elements such as semiotic borders, dual coding and symbols.

The results show that the campaigns are part of four different semiospheres, integrating discursive practices both from advertising and public diplomacy when communicating the national image to the internal (citizens) or external (international) audiences.
\end{abstract}

Keywords: semiosphere, nation branding, semiotic borders, dual coding, national identity

\section{Introduction}

The 2015 campaign promoting Romania as a destination invites people to "escape" to a country where "nature meets history, and castels and mansions match majesty for splendor". The commercial initiated by the Government and broadcasted on National Geographic shows images of Bran Castle (also known as Dracula's castle), Peleș Castle (known for its Bavari-

* National University of Political Studies and Public Administration, Bucharest, Romania. E-mail: bianca.cheregi@comunicare.ro. 
an architectural style), Prahova Valley, the Sphynx from Bucegi Mountains and images of the Carpathian Mountains. This is how a Romanian "escapade" looks like. The last frame presents the country's green leaf logo, symbolizing a fresh, new Romania. Hence, the nation is built as a brand and promoted through a logo, a slogan, and advertising commercials, with the aim of attracting tourists and increase economic development. The techniques used to promote Romania as a touristic destination are inspired from marketing. In this case, nation branding is an effect of the "marketization of public discourse" (Fairclough, 1993).

Nation branding in post-communist Romania is a distinctive phenomena, compared to other countries, especially from Western Europe. In general, in transition countries, nation branding is often mentioned because of the constant need to reconfigure national identity by dissociating it from the communist past. If in Western Europe nation branding is an instrument connected to state power, which uses branding practices to promote the image of a nation in a positive way, in Eastern Europe nation branding is an instrument used to promote the reconfiguration of the political landscape. The campaigns are not just simple instruments to attract investors or tourists, managing to redefine discourses on national identity by refering to myths and national symbols.

One of the most controversial topics in the Romanian media over the past few years is the country image. Soon after the fall of communism in 1989, this issue became part of the public debate about the international perception of Romanian people, about the ways in which Romania is depicted in the international press, or about the country's position in the process of Europeanization. The context in which nation branding is invoked in Romania is linked with the country's democratization process, which started after the anti-communist revolution.

"Does Romania need a country brand?" is the headline of an article published in 2010 in ziare.com, one of the most read Romanian news portal. As we can see, in Romania, nation branding is a public issue discussed in the media, raising the question of why a country brand is needed. Romanian journalists started debating about the nation brand soon after the country started to promote its image in order to attract potential investors, diplomats or tourists (Cheregi, 2015, p. 296). Nation branding was also related to a different debate, about the country image of Romania individually and within the European Union. Therefore, the theme of Romania's country image has launched an intense debate in the media about the promotion campaigns launched by the Government, about the ways in which the international press portrays the country, and about the migrants' actions.

This issue is also a public problem, considering the sociology of public problems (Boltanski, Cefai, Gusfield, 2001), because social actors (such as journalists, consultants, and elites) provide their own definitions and interpretations of the country image in different contexts, some of the explicit (such as nation branding), and some implicit (such as migration as an intensively debated theme in the public sphere). In fact, nation branding is a step in the process of discursively constructing the country image as a public issue (Cheregi, 2015).

Another aspect related to nation branding in transition countries is national identity. As a matter of fact, the post-communist transition provided a discursive framework of reference within which the need for nation branding could be legitimated. In this regard, "nation branding was charged with two tasks: it had to first create the new national identity and then communicate it to the outside world" (Kaneva, 2012, p. 113).

A semiotic approach is necessary to study the discursive construction of nation branding in post-communist Romania, revealing the universe of symbols and meaning employed by the campaigns promoting the country image overseas. In this case, the nation becomes "a 
collection of different rhetoric, images, symbols, and rituals operating at different moments in time and in a variety of spaces" (Aronczyk, 2007, p. 114). As a cultural construct, the national image of a country is related to the symbols promoted internationally. However, does cultural semiotics bring a new way of understanding nation branding in post-communist Romania? If so, how are the advertising discourses related to this new understanding?

In order to answer these questions, this article discusses four nation branding campaigns initiated by the Romanian Government after 1989: Romania Simply Surprising (2004), Romania Land of Choice (2009), Explore the Carpathian Garden (2010), and Discover the Place Where You Feel Reborn (2014). The nation brand is investigated as a sign functioning as a dual code: one dominated by the advertising convention and one of social experiences.

The article starts with a discussion about how nation branding can be investigated from a semiotic perspective. It continues with an overview of the semiosphere concept, understood in the context of the semiotic study of culture. An important issue is the relationship between nation branding and the concept of semiosphere. This theme is discussed considering research in the area of nation branding from a cultural studies approach.

\section{Towards a semiotic analysis of nation branding}

Research investigating nation branding from a semiotic perspective concentrate on spatial semiotics (Giovanardi, Lucarelli \& Pasquinelli, 2013), on social semiotics (Thurlow \& Aiello, 2007), and on modality (Koller, 2008). Thus, their focus is not on the nation brand per se, but more on nation brand's forms of manifestations, such as destination branding (Pike, 2009), country-of-origin effect (Schooler, 1965), or city branding. Methodologically, the studies follow an interpretive approach, involving interviews, examinations of official and promotional texts, participant observation, critical discourse analysis, and case studies.

A semiotic analysis of nation branding permits an in-depth investigation of meanings employed in the campaigns promoting the country image to an international audience. In this regard, the nation brand is understood as an advertising sign, and the campaigns mobilize cultural symbols as systems of signs. Moreover, the nation as a brand is also a semiotic artifact, because nation branding campaigns mobilize a symbolic universe, based on types of national identity discourses and cultural symbols. This article draws on Siefkes' (2012) understanding of artifacts as "culturally shared principles of meaning attribution, without a completely fixed outcome" (p. 62), being invested with different kinds of meaning when used in cultural representations. In the same way, the nation brand becomes "a sign vehicle whose content is its function" (Siefkes, 2012, p. 65), while adopting a certain meaning in a culture.

In this paper, nation branding will be analyzed from a cultural semiotics perspective (Lotman, 2005/1984). From all the semiotic approaches, cultural semiotics offers a proper conceptual framework to analyze nation branding campaigns in post-communist Romania, precisely because the campaigns mobilize cultural symbols as systems of signs. In this regard, the discursive practices and national symbols invoked in the nation branding campaigns of post-communist Romania will be examined in-depth. Secondly, there is a strong connection between the nation brand and the semiotic process related to it. The nation brand is, foremost, an advertising sign, which refers to certain meanings and national symbols. 


\section{The nation brand and the semiotic space of culture}

What does nation branding mean from a cultural semiotic perspective? Is the nation brand part of a semiosphere, considering Lotman's (2005/1864) approach?

Following the Tartu-Moscow-Semiotic School (Lotman, 1984, 1990; Lotman \& Uspensky, 1978; Lotman M., 2002; Kotov, 2002; Kull, 1998, 2005; Torop, 2005), culture appears as a system of signs and rules are a necessary minimal condition for the creation of culture, in the same way as teaching of language as a system of grammatical rules or as a set of usage (Lotman \& Uspensky, 1978, p. 218). The central idea is that culture is built on natural language and represents a "secondary modeling system", because it provides an ongoing model for human knowledge and interaction. The "primary modeling system" is the language capacity, considered to be a natural system. In this context, the sign is any reality drawn into the sphere of culture.

In 1982, Juri Lotman, founder of the Tartu-Moscow Semiotic School, formulated the concept of semiosphere, under the influence of Vladimir Verdansky's (1967) concept of biosphere. As a cosmic mechanism, the biosphere occupies a special place in the planetary unit, a space filled with living matter, which is "the totality of living organisms" (Verdansky, 1967, p. 350). Therefore, the biosphere is also the condition for the continuation of life. In the same way, the semiosphere is the result and the condition for the development of culture. In Lotman's opinion, the semiosphere is the "semiotic space necessary for the existence and functioning of languages" and "outside the semiosphere, there can be neither communication, nor language" (2000/1990, pp. 123-124). Furthermore, semiosphere is "the semiotic space, outside of which semiosis cannot exist" (Lotman, 2005/1984, p. 205).

In fact, the idea of semiosphere is based on the fact that "dialogue precedes language and generates the language", which means that "without semiosphere a language does not only not work, but does not even exist" (Lotman, 2005/1984, p. 216). In order to illustrate the semiotic universe, Lotman gives the example of steaks: if one sticks together individual steaks it will not result a bigger steak. Therefore, by sticking together separate semiotic acts, a semiotic universe will not be obtained. On the contrary, "only the existence of such a universe the semiosphere - makes the specific signatory act real" (Lotman, 2005/1984, p. 208).

Kalevi Kull (2005) mentions sixteen different definitions in order to present the concept of semiosphere. Some of them are related to the meaning-generation process, while others consider the space of diversity and multiple worlds: "semiosphere is a web of sign processes, or semiosis", "semiosphere is the sphere of communication", "anything from the (endless) web of interpretations", "the space of semiosis", "the space of whole-part relations" or "the world of multiple truths, of multiple worlds" (Kull, 2005, pp. 179-180). Furthermore, Kull argues there is a connection between the concept of semiosphere and that of Umwelt, considering Jakob von Uexküll's perspective. Umwelt means the personal semiotic space and semiosphere becomes "a set of all interconnected Umwelten. Any two Umwelten, when communicating, are a part of the same semiosphere" (Kull, 1998, p. 305). Umwelt is also the semiotic world of organism, uniting all the semiotic processes of an organism into a whole.

Semiosphere is characterized by a specific structure of space and time whose organization is established through the workings of the semiosphere itself (Kotov, 2002, p. 47). The outside world is subject to semiotisation and it is divided into "domains of objects which signify, symbolize, indicate something (have meaning), and objects which simply are themselves" (Lotman, 2000/1990, p. 133). Peteer Torop (2005) argues that the concept of 
semiosphere is very close to the concept of symbol in symbolism. For example, the symbol is suitable both for "conveying the cognition of incongnizable" and for "having an enormous semantic volume as a reduced myth" (Torop, 2005, p. 161). Notwithstanding, for Mihhail Lotman (2002, p. 35), the concept of semiosphere is based on the crisis of identity: "for its own existence, every semiotic entity (sign, text, mind, or culture as a whole) needs the other". Put simply, sign, text, culture can exist only among other signs, texts, and cultures.

In this article, the concept of semiosphere is based on Lotman's definition, understood as the semiotic space necessary for the existence and functioning of advertising discourses and as the space of meaning generation. The concept is applied to investigate the nation branding campaigns, and particularly the commercials promoting the country image overseas. An interesting fact here is that nation branding campaigns integrate discursive practices both from advertising and public diplomacy when communicating the national image to the internal (citizens) or external (international) audiences. These campaigns mobilize a symbolic universe, based on types of national identity discourses and cultural symbols.

Asking whether there could be several semiospheres, Kull (1998, p. 308) argues that this may be possible only if there are no semiotic processes to connect the semiospheres, but "when communication takes place between the spheres, they evidently form one and the same semiosphere". The communication is realized through the semiotic borders, which function as translation mechanisms. The point of contact between two elements of the semiosphere can also lead to the emergence of new meaning. Based on the same logic, the advertising messages from the nation branding campaigns can communicate only through the semiotic border, understood here as translating mechanisms between the nation as a brand and the audience.

The semiotic borders function as integrating principles, because they facilitate the contact between the semiospheres. The most important feature of the borders of semiosphere is their role as translation mechanisms. They have the function of separating and creating identities by juxtaposing the own and the alien (Torop, 2005, p. 164). In the case of nation branding campaigns, the own identity is given by the national symbols employed, while the alien is the neoliberal commercialism, which relies on the commercial mechanism to promote the country. This is the situation in post-communist countries, different compared to the Western approach on nation branding, because of the countries' need to dissociate from the communist past.

The borders of semiosphere are double-coded systems of translation filters. This way, "any text to be translated should be at first recognized by a previous text", and the "outcome of translation will influence the recognition process" (Kull, 1998, p. 304). The advertising messages are also double-coded, being embedded in a specific convention that influences the outcome of translation. Another concept related to the borders of the semiosphere is semiosis, understood as a process of translation. In this context, semiosis "always requires a previous semiosis which produced the translator" (Kull, 1998, p. 304). Also, the text used for translation is the product of previous semiosis. This leads to the fact that semiosis is turned into an endless chain and every metal ring is a semiosis that comes from semiosis. Considering this facts, the advertising discourses are based on a previous semiosis, translating the national images into commercial objectives. 


\section{Semiosphere and nation branding. A cultural semiotic approach}

The most important feature of the semiosphere is the border and its role as a translation mechanism. Thus, the process of creolisation between two systems may lead to cultural homogenization, because when "two systems are relatively similar, translation filters may fail and the element of alien culture may enter given culture unnoticeable" (Kotov, 2002, p. 51). For example, in Estonia there is a confrontation between the national values and the policy of multiculturalism, emerging after the 1990s. The alien culture is the cultural diversity or the multiculturalism, while the national values are connected to the country as a whole. The same thing has happened in Romania, after the Revolution of 1989, when there was a confrontation between the national identity in communism and the national identity in post-communist. Consequently, a reconfiguration of the political landscape was neccessary, so dictatorship was changed to democracy and an open market economy emerged, along with a liberated media.

If the semiosphere is the result and the condition for the development of culture, then the nation brand is a part of it, because of the national myths employed by the tourism campaigns. In this case, nation branding campaigns function as a semiosis, understood as a process of translation. The question that arises here is whether there is communication between the nation brand and the audience outside of the semiotic space. Certainly, nation branding campaigns use translation mechanisms in order to position a nation internationally. Moreover, the text and images used for promoting a tourism campaign are part of the translation process.

Corbu (2009, p. 59) discusses the concept of semiosphere (Lotman, 2000/1990) considering the emergence of global brands, introducing the concept of advertsphere, defined as "the semiotic space outside of which no decoding of advertising sign is possible". The advertising signs are understood as triadic entities: a sign stands for an object (or representamen) to an interpretant (Peirce, 1990).

In contrast with commercial advertising, nation branding campaigns are preoccupied with positioning a nation on the global stage and with consolidating the country's reputation. In this context, the nation brand can be investigated as a cultural space. At the core of the semiosphere lay the most developed and structurally organized advertising discourses, while at the periphery lays the semiotic world of the audience, based on personal experience and cultural background (Linton, 1945). In the case of nation branding campaigns, the border of semiosphere is between different meanings employed through national symbols. Furthermore, the translation mechanism is present when decoding the advertising message. The audience, either if it is internally (the citizens of the state), or externally (other countries' Governments, potential tourists, potential investors, etc.) will decode differently the nation branding campaigns, according to their own semiotic worlds.

Therefore, this article draws on a semiotic analysis linked to a theoretical framework from the field of cultural semiotics (Lotman, 2005/1984), in order to investigate four nation branding campaigns initiated by the Romanian Government after 1989. The campaigns constitute an indicator of how nation branding initiatives are employed in the particular case of postcommunist Romania. The research questions underlying this semiotic analysis are:

RQ1: What are the necessary semiotic conditions for constructing nation branding campaigns initiated by the Romanian Government as semiospheres?

RQ2: How do the advertising discourses function as systems of signs inside the semiospheres? 
RQ3: What types of national identity discourses are employed in the nation branding campaigns (symbols, myths, language)?

RQ4: What is the ideological meaning of the nation branding campaings initiated by the Romanian Government? To what extent are elements of neoliberal ideology addressed?

In order to answer to these questions, the analysis is based on indicators such as semiotic borders, dual coding and symbols.

The semiotic borders function as translation mechanisms, separating and creating identities by juxtaposing the own and the alien. In the campaigns analyzed, the semiotic borders translate the nation brand into images and texts about the country's values.

Dual coding is another indicator, insisting on the advertising messages being embedded in a specific convention that influences the outcome of translation. For instance, the nation branding campaigns employ the same myths in different ways, so the symbols are embedded in the cultural values, and also represented as advertising discourses.

The symbols are the ones generating meaning inside the semiosphere, suitable both for employing national identity values and for representing a country through myths and national patrimony.

The unit of analysis is the tourism campaign promoting Romania's country image overseas. In this regard, four primary units of analysis are taken into account: Romania Simply Surprising (2004), Romania Land of Choice (2009), Explore the Carpathian Garden (2010), and Discover the Place Where You Feel Reborn (2014). The context is necessary to see how nation branding initiatives are employed in the particular case of Romania. The corpus was selected considering the moment when nation branding has become a public issue in Romania, being intensely debated in the public space. Furthermore, since 2005, the country image has been an important topic discussed in the Romanian media as well, raising the question of why a country brand is needed.

\section{"Romania Simply Surprising"}

Since 1996, the Romanian Government has started to promote Romania's country image overseas, and one of the first initiatives was the launch of "Eternal and fascinating Romania" project. Nevertheless, only since 2005 the "theme of Romania's country image is being the object of an institutionalization process" (Beciu, 2011, p. 110), so the Government assumes responsibility for promoting the country internationally, working with consultancy agencies in order to initiate campaigns such as Romania Land of Choice (2009) and Explore the Carpathian Garden (2010). The last one generated a reaction from the media, which started to criticize the Government for the lack of professionalism. Moreover, nation branding is not just a concept, being also a type of public issue (Cheregi, 2015, p. 296) which "passes from the area of institutional and expertise discourses into the area of the public sphere, and generally, in the public discourses, including the quotidian life" (Beciu, 2013, p. 43).

In fact, Romania's first branding activities at governmental level were more isolated actions that integrated communication campaigns (Dolea \& Țăruş, 2009). Put simply, the first approaches "have promoted tangible objects: places to visit in Romania, food, and only after 2005 appeared integrating concepts to present a more complex picture of the country and 
also to embrace customs, traditions, theatre plays and documentary films" (Dolea \& Țăruş, 2009, p. 84).

Hence, in 2003, the Romanian government "launched the country's first long-term branding effort" (Kaneva \& Popescu, 2011, p. 196). The "Romania Simply Surprising" campaign presented touristic attractions such as Bucharest, Transylvania, the monasteries of Bukovina and Maramureş, and the Black Sea coast. It consisted of five television commercials: a 'master-ad' and four 'explanatory' ads (Kaneva \& Popescu, 2011, p. 198). The 'master-ad' begins with an image of a woman playing the violin in the lobby of the Romanian Athenaeum in Bucharest. The woman is dressed in a long white dress decorated with red tassels, looking like a traditional costume. She also wears a coral and silver coin necklace, known as the Romanian salba ${ }^{1}$. The following frames present a larger-than-life model walking on Victoria Avenue and displaying clothes in a fashion show. She rises above the old buildings of the Bucharest centre, gently blowing under the wings of a biplane flying above the city. The commercial alternates traditional motifs with modern ones, presenting a cosmopolitan Bucharest as a touristic destination.

The story is continued with images from the Danube Delta, where a fisherman throws a net in the water. Next, an over-sized model is walking on the beach, near long chairs and sun umbrellas. The visual with the Romanian seaside is continued with an image of the Sphinx of Bucegi from the Carpathian Mountains, where a peasant boy, dressed in a folk costume, shoots a burning arrow into the sky. This is a well known symbol in the Romanian national imaginary. Legend says that Stephen the Great (the prince of Moldavia and one of the best army commanders in Romanian history) shot an arrow from a mountain top and built Putna Monastery where the arrow landed. The mountain is named the "Hill of the Cross" ("Crucişorul") and lies south-east of the monastery. After each medieval battle, the prince of Moldavia would build a church, considering that particular place sacred. Stephen was not the only one shooting arrows. The children bailiff and two messengers shot their arrows too, and the gate of the monastery was erected where the children's bailiff arrow landed. Furthermore, the bell tower was built where the messenger' arrow landed.

In the campaign ad, the peasant boy is the symbol of the children's bailiff. His arrow leads to the Voroneț Monastery, where a priest plays a semantron (toaca ${ }^{2}$ to summon the monastics to prayer or to suggest the start of a procession. In the monastery there is a little girl wearing a white dress which opens the palm of her hand to reveal Bran Castle, also known as Dracula Castle. Further, Dracula appears and covers himself with a red veil, changing the frame back to the interior of the Romanian Athenaeum. There, a large screen shows images with the Carpathian Mountains. A smiling woman jumps of the screen, inviting people to visit Romania with an open palm hand gesture.

The other four ads from the "Romania Simply Surprising" campaign reveal the complete stories of Danube Delta, Bukovina monasteries, the Black Sea Coast, and of Bucharest. For instance, in the Danube Delta commercial, a boat is floating near white water lilies, framed followed by images with a lot of birds that also float on the water. Then, we can see the fisherman throwing a net into the Danube. He catches a lot of fishes, and the birds fly above the river. The visuals show pelicans particularly because the Danube Delta is home of the largest colony of pelicans outside Africa. Two children run after the birds in this peaceful place and the fisherman is paddling slowly on the water.

Another commercial is promoting the Bukovina Monasteries. Here, a messenger is shooting a burning arrow which travels through time, passing by Voroneț and Sucevița monaster- 
ies. This is linked to the legend of Stephen the Great, who would shot an arrow from the top of a high mountain and the place where the arrow fell was chosen for a new church. The commercial ends with an image of a nun playing the semantron, a ritual specific to the Eastern Orthodox Church.

As for the Black Sea Coast, the ad shows images with a larger-than-life woman walking on the beach, followed by a young woman jumping off a yacht into the sea. Next, we can see wind-surfers and youngsters running and playing volleyball. The last frame presents two dolphins playing with the ball in the Black Sea. Finally, the fifth commercial introduces a classical and yet modern Bucharest, interesting because of its beautiful buildings such as the Romanian Athenaeum, the Arc of Triumph or the House of Parliament. There are also visuals with new corporate buildings, interfering modern motifs with traditional ones. The music from the spot is romantic, suggesting Francophile aspirations of the capital city, also known as "little Paris". In the end, we can see a bride holding a bouquet of flower, also leading to a romantic ritual.

In the "Romania Simply Surprising" campaign, the nation brand functions as a cultural construct, promoting the national image of the country through symbols such as the traditional Romanian "salba", Bucharest as a "little Paris", the fisherman throwing a net into the Danube, the peasant boy shooting a burning arrow or the semantron (toaca) played at Bukovina monasteries. The nation brand is part of the semiosphere (Lotman, 2005/1984) because of the national myths employed by the campaign, as it can be seen in Figure 1. In this case, they function as a semiosis, understood as a process of translation. The repertoire of symbols in the commercial encompasses a "profound coding mechanism" (Lotman, 1990, p. 101).

Referring to the Romanian national imaginary, the symbols also have "an enormous semantic volume as a reduced myth" (Torop, 2005, p. 161). For instance, the tale of Dracula fits perfectly in the "Romania Simply Surprising" campaign because "the Romanian space represents, for the West, the first circle of otherness: sufficiently close for the curious configurations and disturbing forms of behavior which Westerners find there to be highlighted all the more strongly" (Boia, 2001, p. 9). The image in the ad shows Dracula appearing from Bran Castle, covering himself with a red veil. This leads to a wider discussion about nation branding and the audience's semiotic worlds. There is a preference to the Western audience specifically, because they are familiar with the Dracula story. The internal audience (Romanian citizens) is not so impressed by this tale, especially because it has nothing to do with national history.

The Dracula myth is a cultural treasury of humanity because the novel written by Bram Stoker in 1897 was a successful work of literature. Dracula is also known from the films based on Stoker's novel. In the Romanian history, Vlad Țepeş, the prince of Wallachia from 1456 to 1462 , was called Dracula by foreigners. His cruelty was out of the ordinary, since he impaled people on stakes. Thus, the novel written by Stoker was a work of fiction which is not connected to the real Vlad Țepeș, because the vampire Dracula is not a transfiguration of the prince of Wallachia. An interesting fact here is that the same historical figure "has given rise to two such different myths: on the one hand, a national and political symbol for the Romanians, and on the other, the gothic legend of the vampire" (Boia, 2001, p. 230). Actually, for Romanians, Vlad Țepeș defended the country against Turkish invasion and his cruelties are explained by reasons of state, ensuring order and justice. Foreigners are more familiar with the bloodthirsty Prince, because of Bram Stoker's successful novel. 
Figure 1. Romania Simply Surprising campaign as a semiosphere.

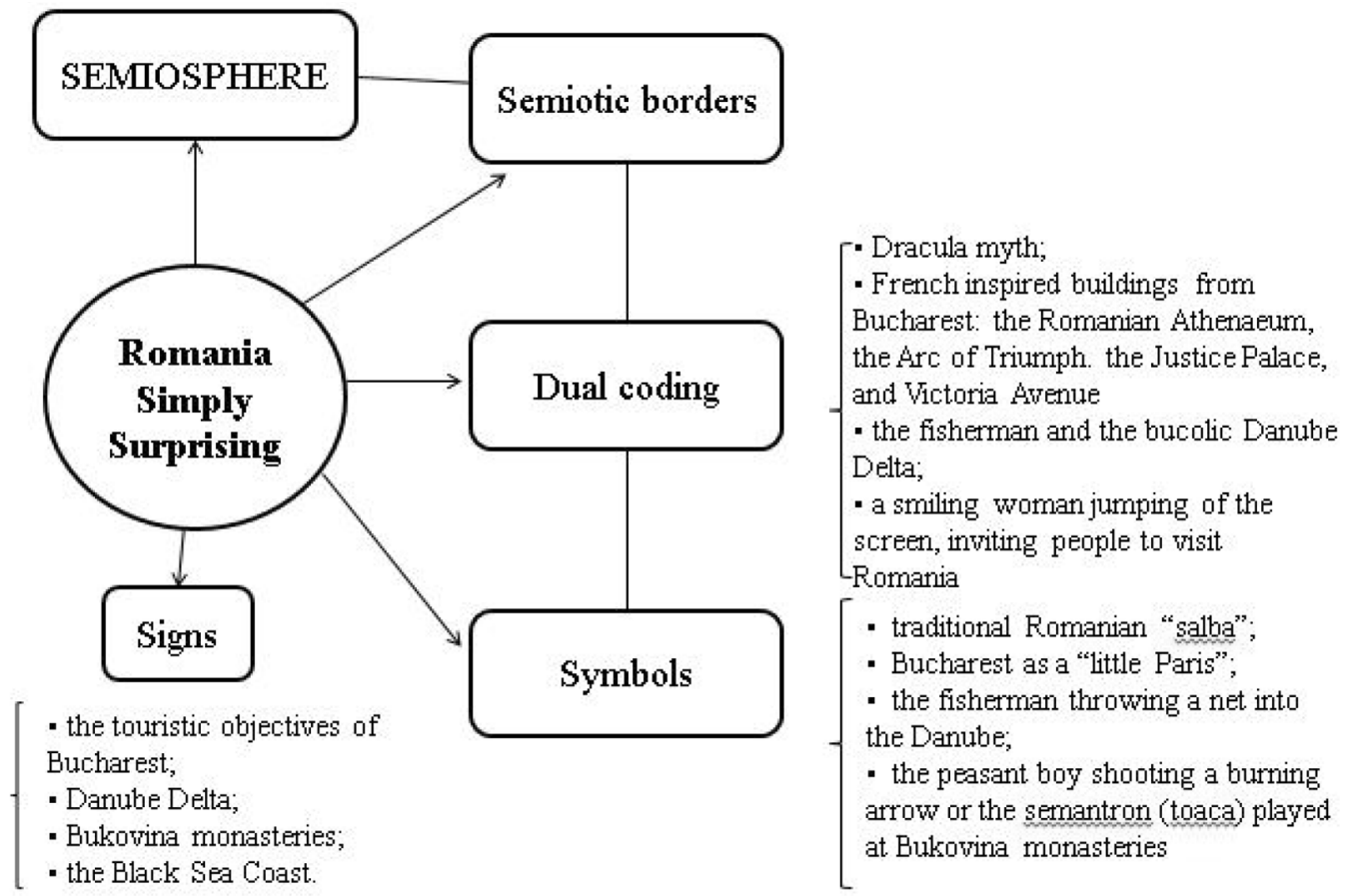

Another myth promoted by the tourism commercial is the myth of Bucharest as a "little Paris", inspired from the city's architecture. Some corners of the capital city do have a Parisian look. Buildings such as the Romanian Athenaeum, the Arc of Triumph or the Justice Palace are French inspired, along with the Victoria Avenue (Calea Victoriei), one the symbolic axis of the capital. In the ad, the over-sized model walks on the Victoria Avenue displaying new clothes design, like in a Paris fashion show. Considering the nation brand as part of a semiosphere, the semiotic border interferes here a translation mechanism between the Romanian and French cultures. The point of contact between elements of different cultures enables the emergence of new meaning. Bucharest looks like a "little Paris", with a similar architecture and interesting fashion shows. This new meaning is appealing also to an international audience, interested in discovering a romantic city.

The fisherman and the bucolic Danube Delta suggest a peaceful place to visit. It is possible to relate the image of a fisherman throwing a net into the Danube with the fairy tale of the fisherman and the fish. "Golden fishes" are waiting to be caught in order to fulfill any wish in exchange for their freedom. The nation brand as discursively constructed in the "Romania Simply Surprising" campaign can be investigated as a cultural space. At the core of the semiosphere lay the national myths, while at the periphery lays the semiotic world of the audience, based on its cultural background (Linton, 1945). The campaign also uses national identity discourses, implying that there is a relationship between nation branding and national identity. Notwithstanding, Kaneva and Popescu (2011, p. 201) believe that putting "interbellum Bucharest, Parisian fashion, Danube fishing, Dracula and monasteries into the same 
ad results in a confusing concoction of disparate myths", indicating "the lack of internal consensus over the meaning of national identity in Romania". Thus, the campaign appeals to symbols only familiar to an internal audience, such as the traditional Romanian "salba" or the burning arrow. The symbols appeal to the Romanian traditions and imaginary and may not be fully understood by an international audience. For a foreigner unfamiliar with Romanian history and myths, these elements are not so well integrated in the narrative logic.

The touristic objectives of Bucharest, Danube Delta, Bukovina monasteries, and of the Black Sea Coast function as signs in the "Romania Simply Surprising" campaign. As Lotman (1978) argues, "any reality drawn into the sphere of culture begins to function as a sign" (p. 229). These signs are dually coded: first, they have a code dominated by the advertising conventions (every place is linked to a specific story, images are selected in order to sustain the national myths); second, the touristic objectives as signs have a code dominated by the social experiences of people visiting Romania (fashion shows, bucolic nature, smiling women, symphony concerts). The nation branding campaign aims at attracting other countries' Governments, potential tourists, potential investors along with the citizens. The master ad from "Romania Simply Surprising" campaign ends with a large screen showing images with the Carpathian Mountains. A smiling woman jumps of the screen, inviting people to visit Romania with an open palm hand gesture. This indicates a commercial inside the nation branding commercial, or a metalanguage. Being a system of a secondary order, the metalingual phenomenon is concerned with signs of signs. The screen showing images with the Carpathian Mountains has its own functions in the commercial, completing the touristic objectives of Romania. The woman jumps from the screen inside the Romanian Athenaeum, connecting the two signs.

Overall, in Romania Simply Surprising campaign national identity discourses are constructed by appealing to traditions (the Romanian salba, the fisherman throwing a net into the Danube), history (the peasant boy shooting a burning arrow), architecture (Bucharest as a "little Paris"), and religion (the semantron played at Bukovina monasteries). To some extent, elements of the neoliberal ideology are addressed by presenting the legend of Dracula and a cosmopolitan Bucharest as a touristic destination. In this regard, there is a relation between nation branding and neoliberal ideology, taking into account the fact that nations are perceived as brands in the age of globalization. This happens because of the capitalist logic, which puts an emphasis on competitive markets. In the case of Romania Simply Surprising campaign, the competitive advantage is given by Francophile aspirations, international myths (the tale of Dracula), culture, and tourism (the touristic objectives of Bucharest, Danube Delta, Bukovina monasteries, and of the Black Sea Coast). Moreover, Bârdan and Imre (2012) consider that we are dealing with "vampire branding" when promoting Romania, because of the multiple uses of Dracula story in the tourism campaigns. A possible explanation for using Dracula myth in nation branding campaigns is that they aim to attract Western audiences.

\section{"Romania Land of Choice"}

In 2009, the Ministry of Tourism launches the "Romania Land of Choice" campaign, in collaboration with the advertising agency ADDV Euro RSCG in co-branding with BRD Groupe Societe Generale. The videos were broadcasted on CNN and Eurosport, promoting Romania as an international tourism destination. Three brand ambassadors were chosen to rep- 
resent the country image: Gheorghe Hagi, Nadia Comăneci and Ilie Năstase. The campaign consists of two television ads: the official tourism commercial and the mocking one, featuring the same three brand ambassadors.

Foremost, the official video starts with an image of Nadia Comăneci (the first female gymnast to be awarded a perfect score of 10 at the Olympics) introducing herself: "Hi! I'm Nadia Comăneci and this is Romania!". Next, the visual shows an image with Sucevița monastery and two nuns walking in the monastery's court. Another frame presents a shepherd leading his sheep in a pastoral landscape. This could be related to the ballad of Miorița, one of the best known Romanian folk creations. The tradition of gliding down the sheep for wintering is also represented.

The picture of a rural Romania is followed by an urban one, showing Sibiu, the European capital of culture. The following frame brings back the rural in an image of a Romanian village house. Ilie Năstase (former World number one professional tennis player) appears in the commercial, landing down in the house garden by using a parachute. He also introduces himself: "Feeling sleepy already? I'm Ilie Năstase and this is Romania". We can now see a different Romania, where people are partying in the club. The story continues with visuals of the Carpathian Mountains and of Vidraru Lake. A coloured ball hits Ilie Năstase and returns to Gheorghe Hagi (considered the greatest Romanian footballer of all time). After introducing himself by saying "I'm Gheorghe Hagi and this is Romania", he throws the ball to the Black Sea Coast, where people are playing and jumping in the water. Next, the images present the Danube Delta, a fisherman floating on a boat, birds flying and wild horses from the Letea Forest running. The commercial ends with Gheorghe Hagi running on the Black Sea Coast and a voice-over saying: "One country, so many experiences. Come to Romania, the land of choice".

Compared with the "Romania Simply Surprising" campaign, the commercials from "Romania Land of Choice" campaign have a discursive component. Visual images are reinforced by the brand ambasadors' comments, and also by the voice-over ending the spot. The three celebrities function as narrators, introducing different stories about Romania. From a cultural semiotic point of view, Nadia Comăneci, Ilie Năstase and Gheorghe Hagi are translators, connecting different elements of the same nation brand. Moreover, Romania's nation brand is part of a semiosphere, because it is the space of meaning generation and of whole-part relations. In fact, the whole is the country as a "land of choice", while its parts are Bukovina monasteries, the pastoral landscapes, the European cultural capital, the Carpathian Garden, people partying, the Black Sea Coast and the Danube Delta (Figure 2). These elements are also signs revealing national identity symbols.

For instance, the shepherd leading his sheep in a pastoral landscape sends to the mythballad of Miorița, one of the best known Romanian folk creations. The bucolic image is a symbol of the "mioritic space", defined by the Transylvanian poet and philosopher Lucian Blaga (1968) as the stylistic matrix of Romanian culture. Furthermore, the "mioritic space" is connected to the Romanian identity, being a way of locating the Romanian poetic spirit. Besides national identity symbols, the commercial also introduces the openness to Western values, when presenting images with Sibiu. If in "Romania Simply Surprising" campaign, the focus was on Francophile aspirations, portraying Bucharest as a "little Paris", addressing mostly to a Western audience, here the focus is on European values. Further, the "Romania Land of Choice" campaign constructs a „,superficial, performative discourse of a stable and homogeneous national identity, suitable for external consumption, that does not necessarily reflect the popu- 
lar sentiments of the citizenry" (Kaneva, 2012, p. 118). This can be explained by the postcommunist countries' need to redefine their national identity, seeing the Western model as a successful one. The slogan from the end is suggesting unity in diversity: "One country, so many experiences", which leads to the need for a European identity. The semiotic border marks the place of Romania in a European context, implicitly expressing the country's desire to join the European Union.

Figure 2. Romania Land of Choice campaign as a semiosphere.

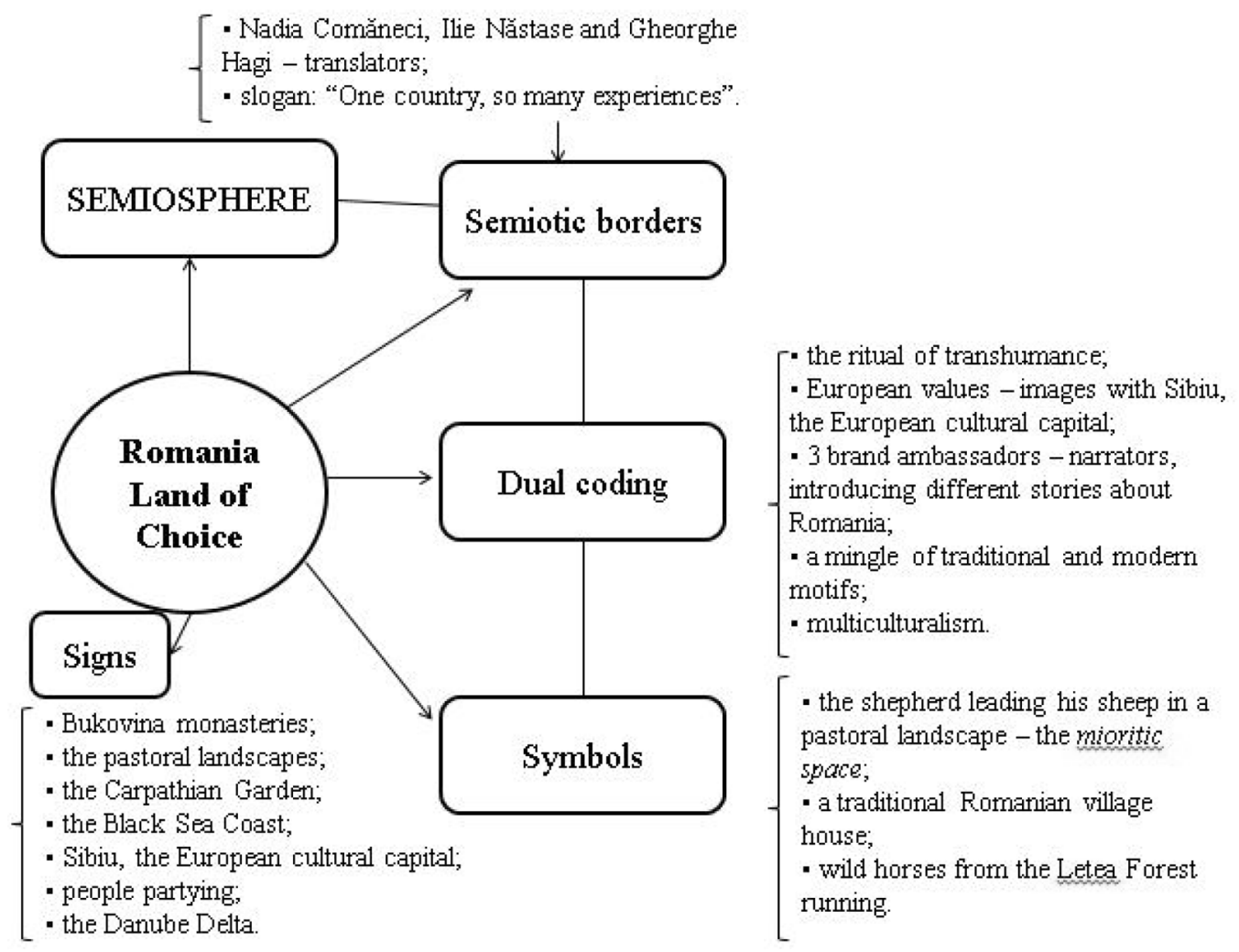

The mocking commercial of "Romania Land of Choice" campaign challenges fictional projections about Romania. It begins with the image of a happy bride in the company of four men dressed in suits. Nadia Comăneci presents this scene by explaing that "this is Romania, the only country where a woman has the right to marry four men at the same time!". Next, we can see an image with people riding zebras in front of the Bucharest's House of People. Ilie Năstase invites potential tourists to discover Romania, the place where people are riding zebras. Last, Gheorghe Hagi talks about fish fruits and the visual shows a tree full of hanging fish. A voiceover says: "You know nothing about Romania, do you? It's time to come and discover it: real sites, real experiences, real people".

This commercial is addressing to an internal and external audience, inviting potential tourists to discover the real Romania, not the one from the fictional projections. The nation brand is constructed through a mocked discourse, trying to function as a platform for con- 
sumer identification. In this case, "nation branding is promoted, paradoxically, in the guise of a post-national order that magically relieves individuals on nationalism's ideological burden and converts its pleasures into a platform for consumer identification" (Bârdan \& Imre, 2012, p. 186). At the core of the nation brand lay the most developed commercial discourses, while at the periphery lay the semiotic world of the audience, which will decode differently this parody ad. The Romanian citizens may find the ad ridiculuous, because it is based on a fictional portrait of Romanian people. On the other hand, an international audience may be confused about this mocking ad, especially if they are not familiar with Romania at all. The last frame revealing a tree full of hanging fish is implicitly suggesting people not to believe everyting they hear about Romania. Actually, the ad invites potential tourists to visit Romania in order to improve their knowledge about this country.

The Romania Land of Choice campaign presents different stories about Romania, introduced by three celebrities that function as translators, connecting different elements of the same semiosphere. In this cultural space, national identity discourses are constructed by appealing to the psychological profile of the Romanian people (the mioritic space, the inalienable matrix of the national spirit; Romania people partying), to traditions (a Romanian village house), religion (Bukovina monasteries), geography (pastoral landscapes, the Carpathian Garden) and modernization (images with Sibiu, the European Cultural Capital). Moreover, the campaign defines Romania's nation brand by using a language from commercial discourses ("One country, so many experiences", "Land of Choice", "This is Romania"). As a matter of fact, the campaign title "Land of Choice" is a cliché representation of what capitalist economies like to represent themselves as offering, addressing the neoliberal ideology as well. This is connected to the "marketization of public discourse" (Fairclough, 1993), so Romania's nation brand is part of a semiosphere where the capitalist logic of the market is an important element. Besides this, the commercial ad presents the country in a European context, insisting on images with Sibiu, the European Cultural Capital in 2007.

\section{"Explore the Carpathian Garden"}

Three years after Romania's EU accession in 2007, the Ministry of Regional Development and Tourism has launched the 'Explore the Carpathian Garden' tourism branding campaign at the World Exhibition in Shanghai, aiming to create a positive image of Romania. The development of Romanian tourism was financed with European funds ( 75 milion Euros until the end of 2013), such as the European Fund for Regional Development. The Spanish agency Asesores en Turismo y Hotelera Recreacion - Taylor Nelson Sofres has created the new country brand with the green leaf logo. Romanian bloggers have criticized the logo, because of its resemblance with the logo of the British company Change Transport. The information first appeared on a blog, with the headline "Discover the differences between the two images. The Ministry of Tourism is stealing images for the nation brand logo". ${ }^{3}$ The Romanian media has rapidly disseminated this information, debating about the necessity of a country brand. The Tourism Minister Elena Udrea was criticized for the nation branding campaign, and several articles in the press mentioned "Elena Udrea's leaf". Citizens had the opportunity to express their opinions about the campaign, in the context of a high media attention to the nation brand issue.

The "Explore the Carpathian Garden" campaign consisted of commercials, media campaigns, as well as websites for potential tourists which include a trip planner. A trilogy of 
documentaries entitled Wild Carpathia was also launched, supported and recommended by Prince Charles. The documentaries were broadcasted on Travel Channel and presented Romania's natural beauties. Compared to the first nation branding initiatives ("Simply Surprising" - 2004, "Land of Choice" - 2009), this campaign used various communication channels, including the Internet. The analysis will insist only on the three TV spots: a general one, a nature and a cultural themed one, promoted on CNN, Eurosport and Euronews. The ads show images accompanied by words, while the voice-over uses all the words from the visuals in the discourse. In the general commercial, the voice-over says:

\footnotetext{
"From the moment you start your journey to the adventure it becomes, from the inspiring architecture to the discovery of traditions, from nature's finest moments to the feeling of being lost amongst them, for everything Romania has to offer. To the experience you'll take away. Romania, explore the Carpathian Garden"
}

It starts with a foggy, dark forest that becomes brighter. The word "explore" is associated with this image, inviting people to discover what is behind the foggy forest. A beautiful mountain landscape is revealed, followed by another slide show defined by the word "adventure", reinforced by the images of a village house and people riding horses. The "inspiring architecture" is the Romanian byzantine style, shown in visuals with Snagov Monastery, one of the alleged burial sites of Vlad the Impaler (also known as Dracula). The traditions are to be seen in the church painting and in the image of a man creating a traditional clay pot. Nature is connected with wild mountain landscapes and a picture of yellow flowers. The story continues by revealing images reinforced by authenticity: the Merry Cemetery and children wearing folk costumes.

The commercial also insists on the uniqueness attribute of the touristic brand, showing Peleș Castle, a masterpiece of German new-Renaissance architecture, and the historic centre of Sighişoara, the medieval town known as the Saxons of Transylvania. The image of the Sighişoara citadel is completed by the word "experience". The final frame shows a stage with opening curtains from the National Theatre Bucharest, a public cultural institution. This leads to the social experiences that the audience can enjoy such as the medieval festival and the theatrical plays. Compared to the "Romania Land of Choice" campaign, where three celebrities introduced different stories of the destination brand, here the narrator is explaining the story behind images, like in a film documentary. He introduces the audience into a different world, one of "adventure", "architecture", "traditions", "nature", "authenticity", "uniqueness" and "experiences". The words from the spot are also attributes of Romania's nation brand, involving the consumer or tourist identification.

From a cultural semiotic point of view, the narrator functions as a translator, connecting different elements of the same nation brand. Moreover, Romania's nation brand is part of a semiosphere, because it is the space of meaning generation and of whole-part relations. The whole is the country as a Carpathian Garden, an idea connected to its geographical position. Romania is an Eastern European country situated in the "Carpato-Danubiano-Pontic" space, with the Carpathians at the center. In this case, the nation brand parts are the mountain landscapes, Snagov Monastery, the Merry Cemetery, the European cultural capital, Peleș Castle, the medieval Sighișoara, and children dressed in folk costumes. These elements are also signs revealing national identity symbols (Figure 3 ).

For example, the Merry Cemetery is a cultural artifact, a place where dead is represented in a joyful manner and each cross is colorfully-painted, with a poem for an epitaph. It is a 
cultural artifact that entails the idea of life after death, according to which individuals continue to exist symbolically in their communities even after they die. The "epitaphs summarize the core normative system of the community and thus help to preserve social norms: the epitaphs become the embodiment of the shared worldview in this community" (Curseu \& Pop-Curşeu, 2011, p. 384). The joyful aspect of the monument sends to a Dacian tradition. For Dacians, death is the moment when they meet with Zalmoxis, being a motive of joy and celebration, and not one of mourning, black veils, or regrets. Conversely, after the Roman Empire conquered Dacia, the Romanization also changed the funeral rites into public representation of grief. Thus, the humorous epitaphs from Merry Cemetery entail a very old Dacian myth, also mentioned in the Romanian ballad Miorița, where death is represented as a wedding. Moreover, the "dark carnival of death is allegorized as the luminous carnival of wedding" (Eliade, 1972, p. 242). Imagining death as a happy event is deeply rooted in one of the Romanian most profound myths. The commercial presents the image of the Merry Cemetery reinforced by the word "authentic", because its symbol explores a very old Dacian tradition.

The national symbols are culturally connoted, revealing also deep-rooted myths. In a qualitative analysis of the "Explore the Carpathian Garden" campaign, Creț (2011, p. 36) argues that the videos are built on four myths: myth of rural space and traditions; myth of mysterious, mystical space (Dracula myth); myth of wild nature and myth of culture and traditions related to the church". These myths are employed in the nation branding campaign to seduce the audience with a story they can identify with.

Second of all, the cultural themed spot of the campaign explores images of the Transfăgărășan, of Sibiu, of painted monasteries and people dressed in a traditional outfit. The voice-over is the narrator that explains the visual story: "from the moment you start your journey to the adventure it becomes, from the unique culture to the discovery of France, from the first look at the past to everything Romania has to offer." It starts with a visual from the Carpathian Mountains, followed by Transfăgăăşan and the quote from Top Gear, who named it the most beautiful road in the world. Next, Sibiu is presented as an idylic town, also known as the European Capital of Culture. The third commercial from "Explore the Carpathian Garden" campaign is showing the Danube Delta, mountain landscapes and a pastoral image of sheep. This sends to the myth-ballad of Miorița, revealing a "mioritic space" as as the stylistic matrix of Romanian culture (Blaga, 1969). 
Figure 3. Explore the Carpathian Garden campaign as a semiosphere.

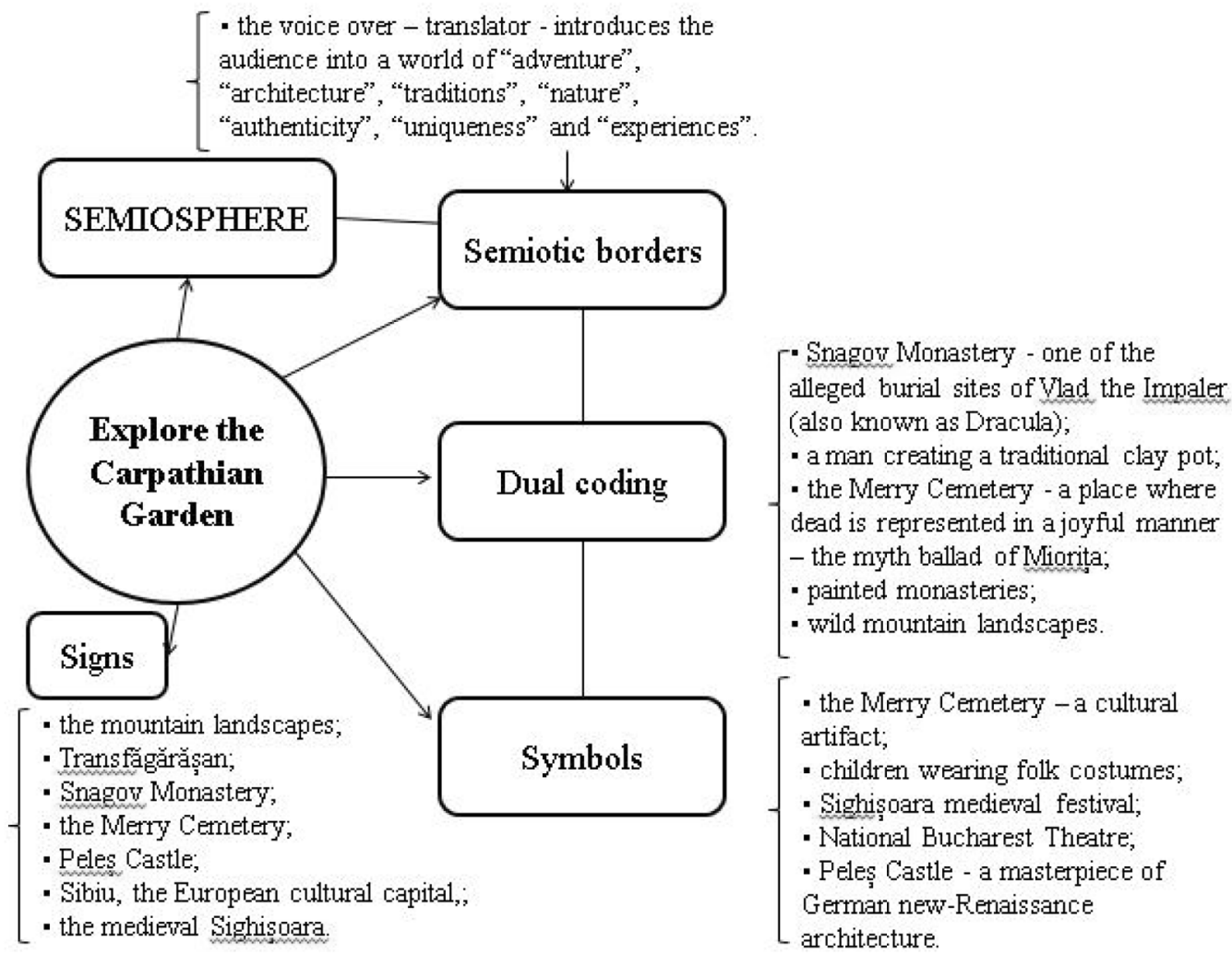

At the core of Romania's nation brand lays the advertising discourses (presenting Romania as an adventure, as a take-away experience), while at the periphery lays the semiotic world of the audience. "Explore the Carpathian Garden" addresses to the potential tourists, inviting them to visit Romania and experience "nature", "authenticity", "uniqueness" or the "mystical". On the other hand, at the periphery lays the international audience, which will decode the advertising message according to their own social experiences. The commercial insists on experiences, presenting Sighișoara's medieval festival and theatrical plays from the National Bucharest Theatre, inviting potential tourists to enjoy them.

Furthermore, the semiotic analysis of the Explore the Carpathian Garden campaign shows that national identity discourses are constructed by appealing to traditions (children wearing folk costumes, a man creating a clay pot), religion (painted monasteries), modernization (images with Transfăgărăşan, the mountain paved road crossing the southern section of the Carpathian Mountains), geography (the Carpathian Garden), architecture (Peles Castle, the medieval Sighișoara, Snagov Monastery) and the psychological profile of Romanian people (Merry Cemetery - a place where death is represented in a joyful manner). In this cultural space, elements of the neoliberal ideology are addressed by commercial discourses ("for everything Romania has to offer", "to the experience you'll take away", "Romania, explore the Carpathian Garden"), reinforcing the cliché representation of capitalist economies as of- 
fering. In fact, the experiences of Sighişoara's medieval festival, of visiting Peleș Castle, a masterpiece of German new-Renaissance architecture and of seeing the humorous epitaphs from the Merry Cemetery are interpellating the Western audiences, inviting them to "explore the Carpathian Garden”.

\section{"Discover the Place Where You Feel Reborn"}

Discover the place where you feel reborn campaign was launched in 2014 and is part of the "Explore the Carpathian Garden" governmental campaign. Compared to the other three nation branding campaigns, here we have a first person narrator that describes his own experiences:

"Here, in these places is where I wish I was born.

Every time I discover the traditions and the culture from these places I feel alive, I feel reborn.

Romania, Explore the Carpathian Garden”.

Furthermore, the campaign addresses mainly to the internal audience, in order to encourage Romanian people to visit their country. The story follows a man passing through different places in Romania. We can also see him old.

The commercial starts with a frame showing a young man with long hair drinking water from a traditional clay pot. He is wearing a backpack and travels to different places in Romania. Next, the visuals show a frame with the man visiting Voronet monastery, one of the painted churches of Moldavia listed in UNESCO's list of World Heritage sites. The frescoes at Voroneț feature an intense shade of blue known in Romania as "Voroneț blue". The young man is touching the wall of the monastery featuring the "Last Judgement" theme. In the next frame we can see a nun playing the semantron right in front of the monastery.

Further, the man is making a traditional Romanian clay pot, with the help of a village lady. The next frames insist on preseting one of the most important Romanian cultural symbols, Brâncuși's Endless Column. The column is linked to the infinite sacrifice of the Romanian soldiers during the First World War. Besides this, the Endless Column is also the axis mundi or the axis of the world, expressing a point of connection between Heaven and Earth. This space serves as a microcosm of order. For Mircea Eliade, "every microcosm, every inhabited region has a Centre, that is to say, a place that is sacred above all" (1991, p. 39). The rhomboid shapes of the column represent the idea of infinity, connecting Heaven with Earth. In the commercial, the young man is touching the Endless Column, a sculpture linked to the mythical past and a distant cultural memory of the Romanian folkloric tradition (Figure 4). 
Figure 4. Discover the Place Where You Feel Reborn campaign as a semiosphere.

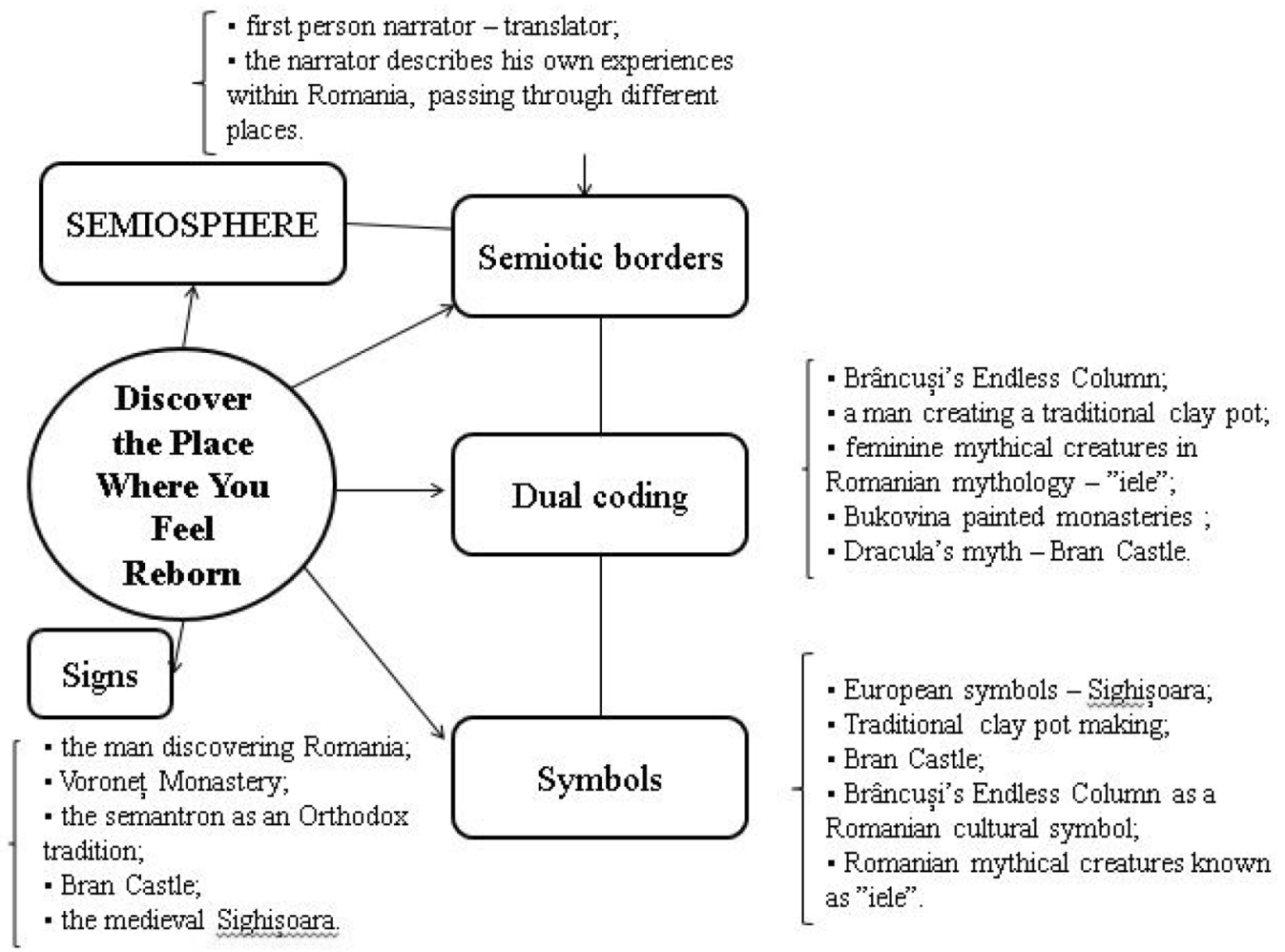

In the following frames, the man is visiting Sighişoara, a medieval Romanian city listed by UNESCO as a World Heritage Site. The image of the Bran Castle is present in this commercial as well, showing the "Dracula castle" from a panoramic view. Therefore, Dracula's myth is reinforced in this campaign, appealing to foreign audiences by interpellating neoliberal commercialism. As I mentioned before in this article, this myth is not representative for Romanian people, even though foreigners are more familiar with the bloodthirsty Vlad Țepes, because of Bram Stoker's successful novel. An interesting fact is that the young man is charmed by beautiful Romania women when discovering the castle. They symbolize feminine mythical creatures in Romanian mythology, known as "iele"4. Similar to the samodivas in Bulgaria, the Romanian fairies have great seductive power over men and magic skills. They are also known as singing and dancing fairies of the night.

In fact, the semiotic analysis of the Discover the Place Where You Feel Reborn campaign shows that national identity discourses are constructed by appealing to traditions (a man creating a traditional clay pot, the presence of the Romanian "evil fairies" know as "ielele"), religion (painted monasteries, a nun playing the semantron), culture (Brâncuşi's Endless Column) and architecture (the medieval Sighişoara, Bran Castle). In this cultural space, elements of the neoliberal ideology are addressed by commercial discourses ("Romania, Explore the Carpathian Garden"), reinforcing the cliché representation of capitalist economies as offering. 


\section{Conclusion}

The results show that investigating nation branding from a cultural semiotic perspective is very useful in understanding the universe of symbols defined by Romania as a destination brand. This article investigated the particular case of advertising commercials, but future research should take into account the relationship between the country image campaigns (including websites, tourism exhibitions, special events, cultural diplomacy, etc.) and the semiosphere. The advertising spots promoting Romania construct a world by appealing to a system of signs and dominant codes. For instance, during the period 2004-2014, Romania was presented as a destination brand through the use of national identity symbols, such as the traditional "salba", the burning arrow, the semantron (toaca), the "mioritic space", and Brâncuşi's Endless Column. These symbols are connected to the Romanian history ("salba", the burning arrow), religion (the semantron), culture (Brâncuși's Endless Column) and the psychological profile of Romanian people (the "mioritic space"). That is why they appeal to the national imaginary, inviting the citizens to identify themselves in the symbols promoted in the nation branding campaigns. Thus, for a foreign audience, the symbols are not known beforehand, which means that the meanings should be constructed through the commercials. In the case of the four campaigns analyzed, a context explaining the symbols is not provided explicitly.

The nation branding campaigns are part of four different semiospheres, integrating discursive practices both from advertising and public diplomacy when communicating the national image to the internal (citizens) or external (international) audiences. The same national symbols (the mioritic space, the semantron, traditional Romanian costumes, painted monasteries) are invoked in different semiospheres, leading to different meanings of the advertising signs. Therefore, Romania's nation brand can be investigated as a cultural space, considering that the campaigns mobilize cultural symbols as systems of signs.

In the Romania Simply Surprising campaign, the touristic objectives of Bucharest, Danube Delta, Bukovina monasteries, and of the Black Sea Coast function as dual coded signs: first, they have a code dominated by the advertising conventions (every place is linked to a specific story, images are selected in order to sustain the national myths); second, the touristic objectives as signs have a code dominated by the social experiences of people visiting Romania (fashion shows, bucolic nature, smiling women, symphony concerts). There is a preference for the Western audience specifically, because they are familiar with the Dracula story and attracted by a French inspired Bucharest. The neoliberal ideology is present in these Western appealing symbols, attracting the tourists to come and visit Romania. On the other hand, only the internal audience (Romanian citizens) is familiar with the traditional Romanian "salba" or the burning arrow, as they send to the Romanian traditions and imaginary. For a foreigner unfamiliar with Romanian history and myths, these elements are not so well integrated in the narrative logic.

As for the Romania Land of Choice campaign, visual images were reinforced by three celebrities functioning as narrators, introducing different stories about Romania. From a cultural semiotic point of view, Nadia Comăneci, Ilie Năstase and Gheorghe Hagi are translators, connecting different elements of the same nation brand. Moreover, Romania's nation brand is part of a semiosphere, because it is the space of meaning generation and of wholepart relations. In fact, the whole is the country as a "land of choice", while its parts are Bukovina monasteries, the pastoral landscapes, the European cultural capital, the Carpathian Garden, people partying, the Black Sea Coast and the Danube Delta. If in Romania Simply Surpris- 
ing campaign, the focus was on Francophile aspirations, portraying Bucharest as a "little Paris", addressing mostly to a Western audience, the focus is on European values in the Romania Land of Choice campaign. The semiotic border marks Romania's position in a European context, implicitly expressing the country's desire to join the European Union

In Explore the Carpathian Garden campaign, the narrator introduces the audience into a different world, one of "adventure", "architecture", "traditions", "nature", "authenticity", "uniqueness" and "experiences". He also functions as a translator, connecting different elements of the same nation brand. At the core of Romania's nation brand lays the advertising discourses (presenting Romania as an adventure, as a take-away experience), while at the periphery lays the semiotic world of the audience, which will decode the advertising message according to their own social experiences. The Sighișoara's medieval festival and theatrical plays from the National Bucharest Theatre are used as social experience symbols, inviting potential tourists to enjoy them.

Discover the Place Where You Feel Reborn campaign is based on a first person narrator functioning as a translator. The man with long hair travels though different places of Romania, discovering Bukovina painted monasteries, traditional clay pots, Brâncuşi’s Endless Column and Bran Castle.

Consequently, national identity is an important component inside the semiosphere, reinforced by national symbols and cultural myths. As for the neoliberal ideology's influence on the construction of the nation branding campaigns, the results show that the campaigns are trying to appeal to Western values by using commercial discourses and the Dracula myth in promoting Romania on the global stage. If Romania Simply Surprising campaign is presenting Bucharest as a "little Paris", insisting on the French inspired architecture, in the Romania Land of Choice and Explore the Carpathian Garden campaigns, the impact of the neoliberal ideology is to be seen in the use of European symbols: Sibiu, the European cultural capital, Peleș Castle, known for its German renaissance architecture, Sighișoara, a medieval city listed by UNESCO as a World Heritage Site. The neoliberal commercialism is more powerfull in the campaign from 2011 ("Explore the Carpathian Garden" campaign), because the objectives were oriented specifically to tourism growth, economic development, and to increasing the competitive advantage on the global stage.

Analyzing Romania's nation brand from a cultural semiotic perspective is only a starting point in finding out how are the cultural symbols and national myths connected to the nation branding campaigns and how do they influence the discursive construction of the nation brand. Future studies should consider cross-cultural research between Eastern European countries, to see if there is a significant resemblance between the campaigns and the cultural imaginary employed. An interesting point would be also to investigate the audience's response to the nation branding campaigns, in terms of their "cultural background".

\section{Notes}

${ }^{1}$ A traditional Romanian necklace made of gold, silver and copper coins.

${ }^{2}$ A percussion instrument made of a long, thick and well-planned piece of timber which is hit in different rhythms by one or two wooden hammers, with a special technique. It is used mostly in Orthodox Christian monasteries. 
${ }^{3}$ The blog article stating the resemblance between the two logos can be found here: http://www.piticu. ro/descoperiti-diferentele-din-cele-doua-imagini.html.

4 "Iele" is the name of "evil fairies" of the Romanian mythology. They are mentioned in old Romanian folktales and legends and they have been a constant source of inspiration for many Romanian writers.

\section{References}

Aronczyk, M. (2007). New and improved nations. Branding national identity. In C. Calhoun \& R. Sennett, Practicing cultures (pp. 105-128). New York: Routledge.

Bârdan, A., \& Imre, E. (2011). Vampire Branding. Romania's Dark Destinations. In N. Kaneva, Branding post-communist nations: Marketizing national identities in the"New Europe." London: Routledge. doi:10.4324/9780203806814.

Beciu, C. (2011). Sociologia comunicării și a spațiului public [Sociology of communication and public space]. Iasi: Polirom.

Beciu, C. (2013). Discursive Reprensentations of Migrants in Political Talk-Shows in Romania. Revista Romana de Sociologie [Romanian Journal of Sociology], (1-2), 41-62.

Blaga, L. (1968). Trilogia culturii [Trilogy of Culture]. Bucharest: Universal Literature.

Boia, L. (2001). History and Myth in Romanian Consciousness. Budapest: Central European University Press.

Cefaï, D. (2001). Les cadres de l'action collective. Définitions et problemes. In D. Cefaï \& D. Trom, Mobilisations dans les arènes publiques. Paris: Ehess.

Cheregi, B.-F. (2015). The Media Construction of Nation Branding in Post-Communist Romania: A Constructivist-Semiotic Perspective. PhD Thesis, National University of Political Science and Public Administration, Bucharest.

Cheregi, B.-F. (2015). The Media Construction of Anti-Immigration Positions: The Discourse on the Romanian Immigrants in the British Press, Revista Română de Sociologie [Romanian Journal of Sociology], (3-4), 279-298.

Corbu, N. (2009). Methodological Issues in Cultural Semiotics of Advertising. Romanian Journal of Communication and Public Relations, 11(3), 59-66.

Crețu, I. (2011). Destination image and destination branding in transition countries: the Romanian tourism branding campaign "Explore the Carpathian garden." University of York.

Curșeu, P. L., \& Pop-Curșeu, I. (2011). Alive after Death: An Exploratory Cultural Artifact Analysis of the Merry Cemetery of Săpânța. Journal of Community \& Applied Social Psychology, 21, 371-387. doi:10.1002/casp.1080.

Dolea, A., \& Țăruș, A. (2009). Branding România: Cum (ne) promovăm imaginea de țară [Branding Romania: How we promote (our) country image]. Bucharest: Curtea Veche.

Dorombach, C. (2010). Descoperiti diferentele dintre cele doua imagini. Ministerul Turismului fura imagini pentru logo-ul de tara. Retrieved from http:/www.piticu.ro/descoperiti-diferentele-din-cele-doua-imagini.html.

Eliade, M. (1972). Zalmoxis, the Vanishing God. (W. Tarsk, Trans.). USA: University of Chicago Press.

Eliade, M. (1991). Images and Symbols. Princeton.

Fairclough, N. (1993). Critical Discourse Analysis and the Marketisation of Public Discourse: The Universities. Discourse \& Society, 4(2), 133-168. doi:10.1177/0957926593004002002

Giovanardi, M., Lucarelli, A., \& Pasquinelli, C. (2013). Towards brand ecology: An analytical framework for interpreting the emergence of place brands. Marketing Theory, (13), 365-383. doi:10.1177/1470593113489704.

Kaneva, N. (2012). Branding post-communist nations: Marketizing national identities in the "new" Europe. London: Routledge.

Kaneva, N., \& Popescu, D. (2011). Nation branding in post-Communist Romania and Bulgaria. International Journal of Cultural Studies, 14(2), 191-207. doi:10.1177/1367877910382181

Koller, V. (2008). "The world in one city": Semiotic and cognitive aspects of city branding. Journal of Language and Politics, 7(3), 431-450. doi:10.1075/jlp.7.3.05kol- 
Kotov, K. (2002). Semiosphere: A chemistry of being. Sign Systems Studies, 30(1), 41-53.

Kull, K. (1998). On Semiosis, Umwelt, and Semiosphere. Semiotica, 120(3/4), 299-310.

Kull, K. (2005). Semiosphere and a dual ecology: Paradoxes of communication. Sign Systems Studies, 33(1), 175-187.

Linton, R. [1945] (1968). Fundamentul cultural al personalității, [The Cultural Background of Personality]. (S. Săraru, Trans.). Bucharest: Editura Științifică.

Lotman, M. (2002). Umwelt and Semiosphere. Sign Systems Studies, 30(1), 33-38.

Lotman, Y. (2004). Culture and Explosion. (W. Clark \& M. Grishakova, Trans.). Berlin: Mouton de Gruyter.

Lotman, Y. (2005) [1984]. On the semiosphere. Sign Systems Studies, 33(1), 205-225.

Lotman, Y., Uspensky, B. A., \& Mihaychuk, G. (1978). On the Semiotic Mechanism of Culture. Soviet Semiotics and Criticism: An Anthology, 9(2), 211-232. doi:10.2307/468571.

Peirce, C. S. (1990). Seminificație și acțiune [Signification and Action]. (D. Marga, Trans.). Bucharest: Humanitas.

Pike, A. (2009). Geographies of brands and branding. Progress in Human Geography, 33(5), 619-645. doi:10.1177/0309132508101601.

Pompiliu, C. (2010). Are nevoie Romania de un brand de tara? Ziare.com. Retrieved from http://www.ziare. com/udrea/ministrul-dezvoltarii-si-turismului/are-nevoie-romania-de-un-brand-de-tara-1018983.

Schooler, R. (1965). Product bias in the Central American common market. Journal of Marketing Research, 2(4), 394-397. doi:10.1002/tie.5060080211.

Siefkes, M. (2012). The semantics of artefacts: How we give meaning to the things we produce and use. In Semiotk (pp. 61-89). Retrieved from http://bit.ly/2mh4iXT.

Thurlow, C., \& Aiello, G. (2007). National pride, global capital: a social semiotic analysis of transnational visual branding in the airline industry. Visual Communication, 6(3), 305-344. doi:10.1177/1470357207081002.

Torop, P. (2005). Semiosphere and/as the research object of semiotics of culture. Sign Systems Studies, 33(1), 159-170.

Verdansky, V. (1967). Biosphere. Moscow: Mysl Publishing House.

\section{Websites}

Havas Worldwide ADDV. (2009, June 12). Romania Land of Choice. Retrieved from https://www.youtube.com /watch?v=YzeKCMNYBew.

ProudtobeRomanian. (2006, June 20). Romania Simply Surprising. Retrieved from https://www.youtube. $\mathrm{com} /$ watch? $\mathrm{v}=$ ByczvQgsbS4\&index=2\&list=PL9D59ABCBACF6B050.

Romania Travel. (2014, June 6). Romania - Discover the place where you feel reborn. Retrived from https:// www.youtube.com/watch?v=iLAF6TQHKa8.

Vadiron. (2011, June 3). Romania, Explore the Carpathian garden - spot general. Retrived from https://www. youtube.com/watch?v=H2ivPX4WVpk. 